\title{
A-Ring-Modified Triterpenoids and Their Spermidine- Aldimines with Strong Antibacterial Activity
}

\author{
Oxana B. Kazakova ${ }^{1, *(\mathbb{D}}$, Jean Michel Brunel ${ }^{2, *} \mathbb{1}$, Elmira F. Khusnutdinova ${ }^{1}\left(\mathbb{D}\right.$, Sophie Negrel ${ }^{2}$, \\ Gulnara V. Giniyatullina ${ }^{1}$, Tatyana V. Lopatina ${ }^{1}$ and Anastasiya V. Petrova ${ }^{1}$ [D \\ 1 Ufa Institute of Chemistry of the Ufa Federal Research Centre of the Russian Academy of Sciences, \\ 71 pr. Oktyabrya, Ufa 450054, Russia; ElmaH@inbox.ru (E.F.K.); gulnaravlg@gmail.com (G.V.G.); \\ ltvioch@yandex.ru (T.V.L.); pnastya08@mail.ru (A.V.P.) \\ 2 Aix Marseille Université, INSERM, SSA, MCT, 13385 Marseille, France; snoly@hotmail.fr \\ * Correspondence: obf@anrb.ru (O.B.K.); bruneljm@yahoo.fr (J.M.B.); Tel.: +7-347-235-6066 (O.B.K.); \\ +33-689-271-645 (J.M.B.)
}

Received: 2 August 2019; Accepted: 5 September 2019; Published: 6 September 2019

check for updates

\begin{abstract}
Synthesis of A-ring-modified lupane, oleanane and ursane type triterpenoid conjugates with spermidine through an aldimine linkage or diethylentriamine via an amide bond is described. These derivatives were evaluated for their in vitro antimicrobial properties against human pathogens. Except for derivatives $\mathbf{1}$ and 7, all compounds have moderate to weak minimum inhibitory concentrations (MICs) against Gram-positive Staphylococcus aureus bacteria, with MICs varying from 3.125 to $200 \mu \mathrm{M}$. Compound 11 is efficient against Escherichia coli and Pseudomonas aeruginosa, with MICs of 25 and $50 \mu \mathrm{M}$, respectively, while all other derivatives do not possess important antimicrobial activities against these Gram-negative bacteria.
\end{abstract}

Keywords: triterpenoids; lupane; oleanane; ursane; spermidine; spermine; squalamine; antimicrobial activity; Gram-positive bacteria; Gram-negative bacteria

\section{Introduction}

Pentacyclic triterpenoids are widely represented in natural products and are useful substrates for the synthesis of various important bioactive compounds [1-3]. Conjugation of a triterpenoid scaffold with amines, amino acids, and polyamines resulted in a series of anticancer, antimicrobial and antiviral agents [4-8]. Chemical antibiotics were one of the great health successes of the 20th century leading to a huge decrease in both morbidity and mortality from bacterial infections. However, this has led to high levels of inappropriate prescribing, which has contributed to a recent rise in the number of antibiotic-resistant bacteria. As a result, multidrug-resistant bacteria such as vancomycin-resistant Enterococcus (VRE), methicillin-resistant Staphylococcus aureus (MRSA), and multidrug-resistant Pseudomonas aeruginosa (MRPA) have appeared [9]. In this context, new types of antibiotics such as antibiotic peptides, lipids, and alkaloids have been isolated as host defense agents from diverse animal species [10-12]. Among these substances, two water-soluble cationic steroids, squalamine, and trodusquemine, have been identified from the dogfish shark Squalus acanthias, exhibiting excellent antimicrobial activities (Figure 1) [13-15]. 

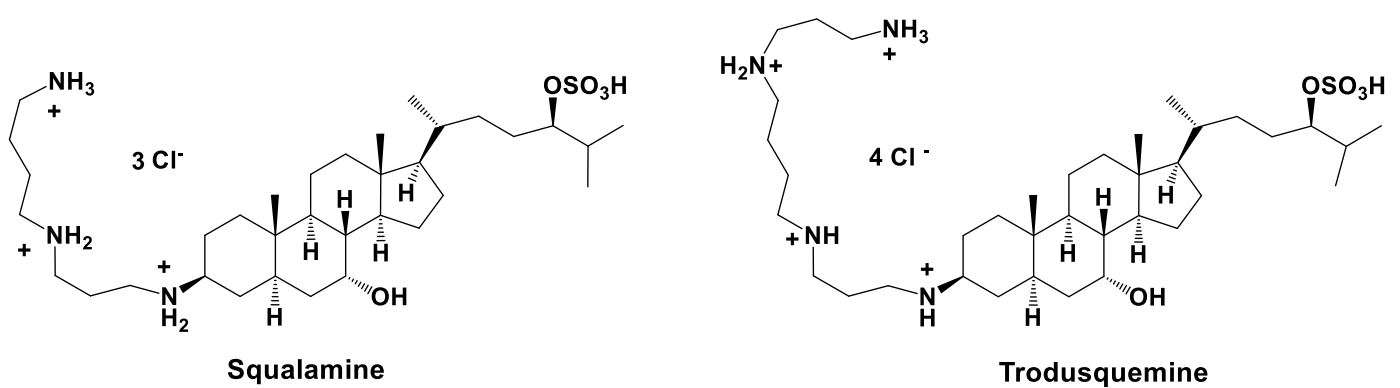

Figure 1. Structure of squalamine and trodusquemine.

Since that time, the synthesis of the triterpenoid analog of squalamine has been accomplished [16], and novel steroidal polyamines, such as Claramine, that exhibit a broad-spectrum antimicrobial bimodal activity, have been discovered $[17,18]$. Polyamines (putrestycine, spermidine, spermine, etc.) play an important role in the physiology of plants and live organisms. They are polycations that interact with negatively charged molecules such as DNA, RNA, and proteins. Betulinic acid-based amides with putrescine and spermine demonstrate a high level of cytotoxicity and antimicrobial activity [19]. At the same time, there are no reports on the synthesis of spermidine conjugates connected to the triterpenoid core via the aldimine group.

In this work, the first synthesis of triterpenoid spermidino-aldimines, as well as some derivatives with an A-azepano-ring and C28-(diethylentriamino)-amides is described and the study of their antimicrobial activity is presented.

\section{Results and Discussion}

\subsection{Chemistry}

The synthesis of a series of nitrogen-containing triterpenoids is presented in Schemes 1 and 2. Azepanobetulin 1 was obtained by several stages from naturally-occurring betulin [20]. The following $\mathrm{p}-\mathrm{TsOH}$ catalyzed rearrangement of compound $\mathbf{1}$ resulted in azepanoallobetulin 2 with a yield of 86\%. Reduction of lupane A-azepanono-C28-nitryl 3 [21] and 2-cyano-3,4-seco-ursolic acid 4 [22] with $\mathrm{LiAlH}_{4}$ under reflux in tetrahydrofurane led to methylenamino-derivatives 5 and $\mathbf{6}$. Betulin and C28-hydroxy-triterpenoids 1 or $\mathbf{6}$ were converted to corresponding aldehydes and were reacted with spermidine in $\mathrm{MeOH}$ under reflux to obtain aldimines 7-9 in yields of $65-72 \%$. The reaction of ursonic or oleanonic acid chlorides with diethylenetriamine led to amides $\mathbf{1 0}$ and $\mathbf{1 1}$ in yields of 85 and $73 \%$, respectively. The data for the latter amide have been previously presented [23].

The structure of the compounds was confirmed by NMR spectroscopy. The ${ }^{13} \mathrm{C}-\mathrm{NMR}$ spectra of azepanes 2, 5 and 8 showed signals of $C-3$ at $d_{C} 62-63$ ppm. For aldimines 7-9, the signals of the $-\mathrm{CH}=\mathrm{N}-$ function were detected at $\delta 169-173 \mathrm{ppm}\left({ }^{13} \mathrm{C}-\mathrm{NMR}\right)$ and at $\delta 7.3-7.8 \mathrm{ppm}\left({ }^{1} \mathrm{H}-\mathrm{NMR}\right)$. In the spectra of compound 10, the signal of amide function $\mathrm{C}(\mathrm{O}) \mathrm{NH}$ was detected at $\delta 178.9 \mathrm{ppm}\left({ }^{13} \mathrm{C}-\mathrm{NMR}\right)$ and at $\delta 6.61 \mathrm{ppm}\left({ }^{1} \mathrm{H}-\mathrm{NMR}\right)$. Finally, the presence of polyamine moieties at position C-28 of the triterpene core in the structure of compounds 7-11 was confirmed by the characteristic signals of the aminomethylene groups $-\mathrm{CH}_{2} \mathrm{NH}-$ at $\delta 2.58-3.70 \mathrm{ppm}\left({ }^{1} \mathrm{H}-\mathrm{NMR}\right)$ (see Supplementary Materials). 


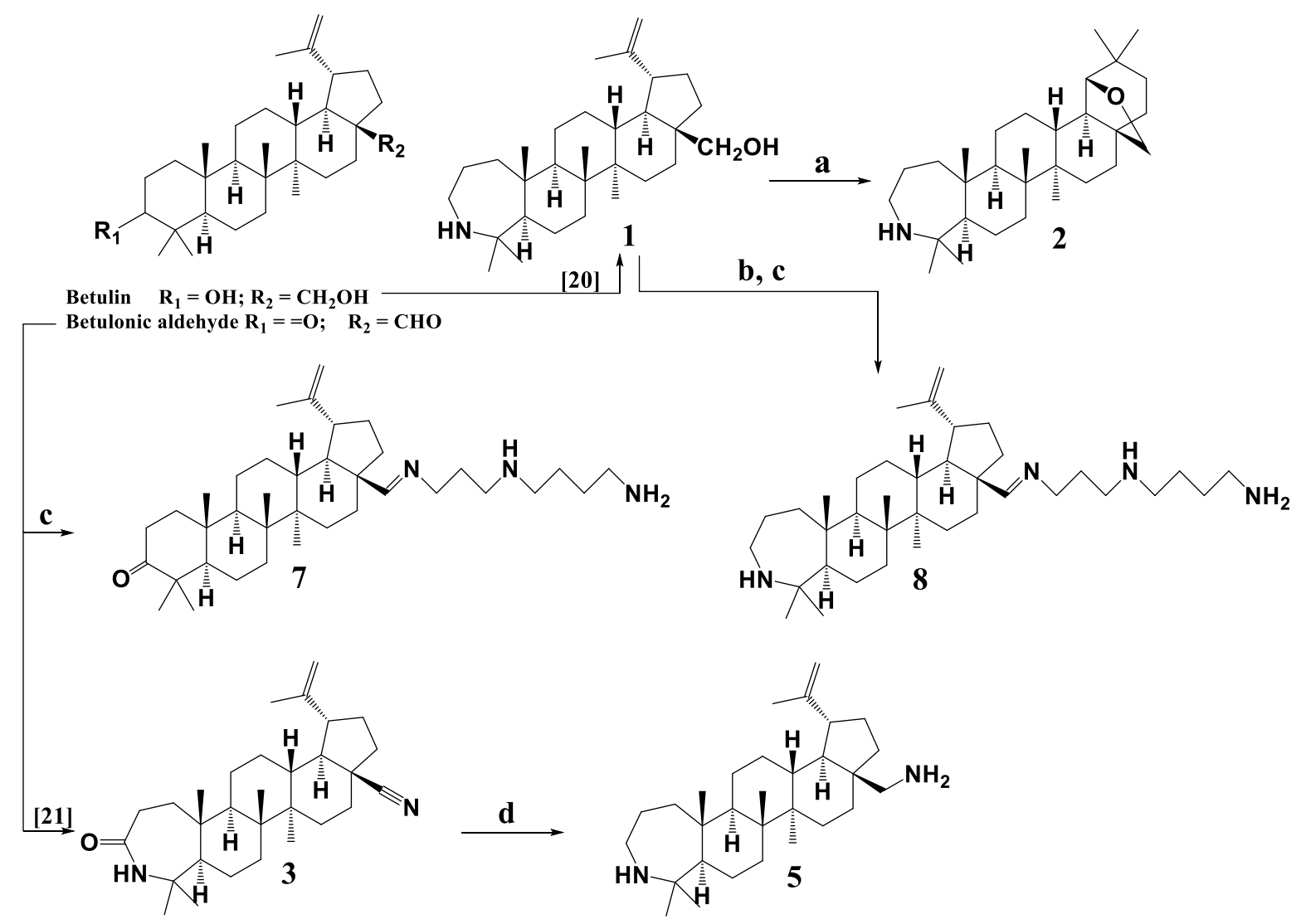

Scheme 1. Synthesis of lupane type derivatives. Reagents and conditions: a. TsOH, $\mathrm{CHCl}_{3}$, reflux, 4 h; b. PCC, $\mathrm{CH}_{2} \mathrm{Cl}_{2}, \mathrm{rt}, 0.5$ h; c. $\mathrm{NH}_{2}\left(\mathrm{CH}_{2}\right)_{3} \mathrm{NH}\left(\mathrm{CH}_{2}\right)_{4} \mathrm{NH}_{2}, \mathrm{MeOH}$, reflux, 8 h; d. $\mathrm{LiAlH}_{4}$, THF, reflux, 3 h.
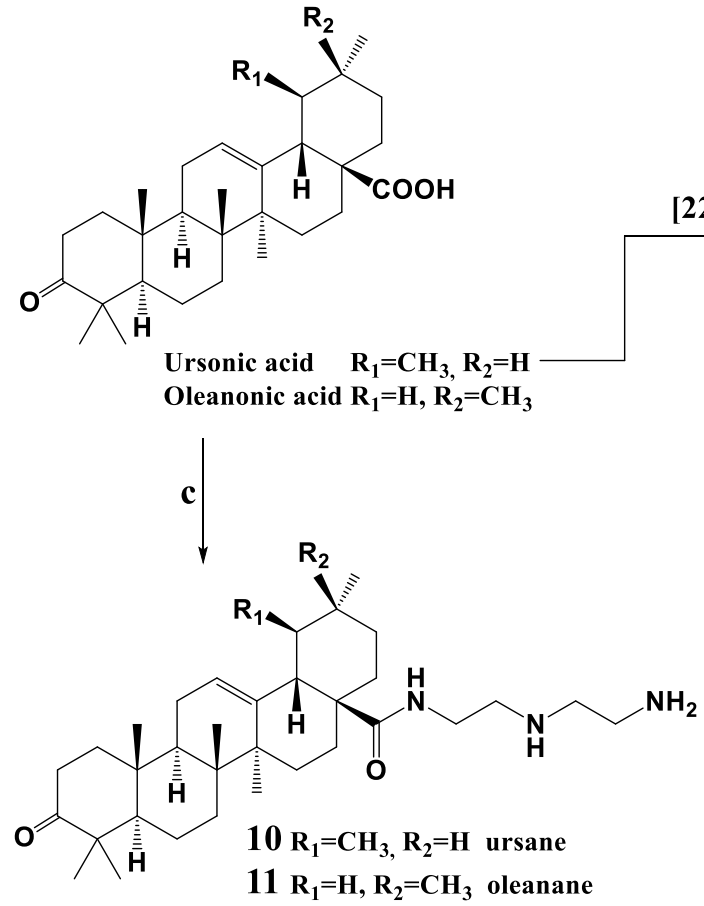

[22]

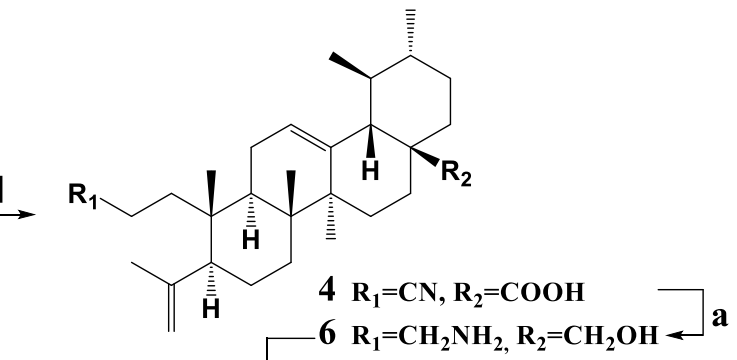

b

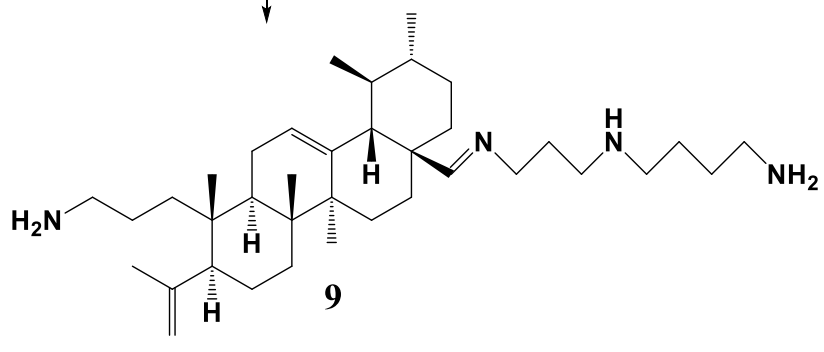

Scheme 2. Synthesis of oleanane and ursane type derivatives. Reagents and conditions: a. $\mathrm{LiAlH}_{4}, \mathrm{THF}$, reflux, 3 h; b. $i$ PCC, $\mathrm{CH}_{2} \mathrm{Cl}_{2}$, rt, $0.5 \mathrm{~h}$, ii $\mathrm{NH}_{2}\left(\mathrm{CH}_{2}\right)_{3} \mathrm{NH}\left(\mathrm{CH}_{2}\right)_{4} \mathrm{NH}_{2}, \mathrm{MeOH}$, reflux, 8 h; c. $i(\mathrm{COCl})_{2}$, $\mathrm{Et}_{3} \mathrm{~N}, \mathrm{CH}_{2} \mathrm{Cl}_{2}, 2{ }^{\circ} \mathrm{C}, 2 \mathrm{~h}$, ii diethylenetriamine, $\mathrm{CH}_{2} \mathrm{Cl}_{2}, \mathrm{Et}_{3} \mathrm{~N}, 20^{\circ} \mathrm{C}, 3 \mathrm{~h}$. 


\subsection{Biology}

All the synthesized compounds were screened for antimicrobial activity against both Gram-positive and Gram-negative bacterial strains and found to possess activities (Table 1). Thus, except for derivatives 1 and $\mathbf{7}$, all compounds have moderate to weak minimum inhibitory concentrations against Gram-positive S. aureus bacteria with MICs varying from 3.125 to $200 \mu \mathrm{M}$. Nevertheless, compound 11 is efficient against $E$. coli and P. aeruginosa, with MICs of 25 and $50 \mu \mathrm{M}$, respectively, while all other derivatives do not possess important antimicrobial activities against these Gram-negative bacteria. It is noteworthy that the minimum bactericidal activity remains of interest for all products active against S. aureus. These data clearly suggest that the nature of the triterpenoid involved plays an important role in the potential activities of our compounds.

Table 1. Minimum inhibitory concentrations and minimum bactericidal concentration of compounds $\mathbf{1}$, 2, 5, and 7-11.

\begin{tabular}{cccc}
\hline \multirow{2}{*}{ Compound } & \multicolumn{3}{c}{ MIC $(\mu \mathrm{M}) / \mathrm{MBC}(\mu \mathrm{M})$} \\
\cline { 2 - 4 } & $\begin{array}{c}\text { S. aureus } \\
\text { DSM789 }\end{array}$ & $\begin{array}{c}\text { E. coli } \\
\text { ATCC25299 }\end{array}$ & $\begin{array}{c}\text { P. aeruginosa } \\
\text { PA01 }\end{array}$ \\
\hline 1 & $>200 />200$ & $>200 />200$ & $>200 />200$ \\
\hline 2 & $6.25 / 25$ & $>200 />200$ & $>200 />200$ \\
\hline 5 & $12.5 / 25$ & $>200 />200$ & $>200 />200$ \\
\hline 7 & $>200 />200$ & $>200 />200$ & $>200 />200$ \\
\hline 8 & $3.125 / 6.25$ & $>200 />200$ & $>200 />200$ \\
\hline 9 & $12.5 / 25$ & $200 />200$ & $200 />200$ \\
\hline 10 & $12.5 / 25$ & $200 />200$ & $200 />200$ \\
\hline 11 & $12.5 / 25$ & $25 / 25$ & $50 />200$ \\
\hline Ciprofloxacine & 0.20 & 0.20 & $>200$ \\
\hline Vancomycine & 0.80 & $>200$ & $>200$ \\
\hline
\end{tabular}

\section{Materials and Methods}

\subsection{General Methods and Physical Measurements}

The spectra were recorded at the Center for the Collective Use 'Chemistry' of the Ufa Institute of Chemistry of the Ufa Federal Research Centre of the Russian Academy of Sciences. ${ }^{1} \mathrm{H}$ and ${ }^{13} \mathrm{C}-\mathrm{NMR}$ spectra were recorded on a "Bruker AM-500" (Bruker, Billerica, MA, USA, 500 and 125.5 MHz respectively, $\delta, \mathrm{ppm}, \mathrm{Hz}$ ) in $\mathrm{CDCl}_{3}$, internal standard tetramethylsilane. Mass spectra were obtained on a liquid chromatograph-mass spectrometer LCMS-2010 EV (Shimadzu, Kyoto, Japan). Melting points were detected on a micro table "Rapido PHMK05" (Nagema, Dresden, Germany). Optical rotations were measured on a polarimeter "Perkin-Elmer $241 \mathrm{MC}$ " (PerkinElmer, Waltham, MA, USA) in a tube length of $1 \mathrm{dm}$. Elemental analysis was performed on a Euro EA-3000 CHNS analyzer (Eurovector, Milan, Italy); the main standard is acetanilide. Thin-layer chromatography analyses were performed on Sorbfil plates (Sorbpolimer, Krasnodar, Russian Federation), using the solvent system chloroform-ethyl acetate, 40:1. Substances were detected by $10 \% \mathrm{H}_{2} \mathrm{SO}_{4}$ with subsequent heating to 100-120 ${ }^{\circ} \mathrm{C}$ for 2-3 min. Betulonic aldehyde [24], compounds 1 [20], 3 [21], ursonic acid and 4 [22], 11 [23] were obtained according to the methods described previously.

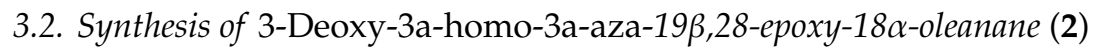

A mixture of compound 1 (220 mg, $0.5 \mathrm{mmol})$ and a catalytic amount of $p$ - $\mathrm{TsOH}(8.6 \mathrm{mg}, 0.05 \mathrm{mmol})$ in dry $\mathrm{CHCl}_{3}(25 \mathrm{~mL})$ was heated under reflux for $4 \mathrm{~h}$, and then the solvent was evaporated under 
reduced pressure. The product was purified by $\mathrm{Al}_{2} \mathrm{O}_{3}$ column chromatography using $\mathrm{CHCl}_{3}$ and a mixture of $\mathrm{CHCl}_{3}-\mathrm{EtOH}$ (100:1) as eluents to afford compound 2 as a beige powder (190 $\mathrm{mg}, 86 \%$ ): $[\alpha]_{\mathrm{D}}{ }^{20}+54\left(\mathrm{c} 0.05, \mathrm{CHCl}_{3}\right)$, m.p. $261^{\circ} \mathrm{C} .{ }^{1} \mathrm{H}-\mathrm{NMR}\left(\delta, \mathrm{ppm}, \mathrm{CDCl}_{3}, 125.5 \mathrm{MHz}\right): 3.62$ and $3.45(2 \mathrm{H}$, both $\mathrm{d}, \mathrm{H}-28, J=7.7 \mathrm{~Hz}), 3.41(1 \mathrm{H}, \mathrm{s}, \mathrm{H}-19), 3.21-3.16(1 \mathrm{H}, \mathrm{m}, \mathrm{H} 3 \mathrm{~b}), 2.91-2.82(1 \mathrm{H}, \mathrm{m}, \mathrm{H} 3 \mathrm{a}), 2.02-1.16$ $\left(26 \mathrm{H}, \mathrm{m}, \mathrm{CH}, \mathrm{CH}_{2}\right), 1.42,1.29,1.01,0.92,0.81,0.74,0.69\left(21 \mathrm{H}\right.$, all s, $\left.7 \mathrm{CH}_{3}\right) .{ }^{13} \mathrm{C}-\mathrm{NMR}\left(\delta, \mathrm{ppm}, \mathrm{CDCl}_{3}\right.$, $500 \mathrm{MHz}$ ): 90.0 (C-19), 72.4 (C-28), 63.0 (C-3), 54.5 (C-9), 48.2 (C-18), 46.6 (C-4), 41.6 (C-5), 41.2, 40.9, 39.9, 36.5, 36.1, 34.4, 33.0, 32.5, 31.5, 28.6, 27.7, 26.6, 26.2, 25.8, 24.4, 22.9, 22.8, 22.0, 21.6, 19.9, 16.2, 15.9, 13.1. Anal. Calcd for $\mathrm{C}_{30} \mathrm{H}_{51} \mathrm{NO}: \mathrm{C}, 81.57 ; \mathrm{H}, 11.64 ; \mathrm{N}$, 3.17. Found: $\mathrm{C}, 81.60 ; \mathrm{H}, 11.54 ; \mathrm{N}, 3.16$. MS (APCI): $m / z[\mathrm{M}+\mathrm{H}]^{+} 442.75$, calcd for $\mathrm{C}_{30} \mathrm{H}_{51} \mathrm{NO}: 441.74$.

\subsection{Synthesis of $\mathbf{5}$ and $\mathbf{6}$}

A mixture of compound 3 [21] (225 mg, $0.5 \mathrm{mmol}$ ) or compound 4 [22] (226 mg, $0.5 \mathrm{mmol})$ and $\mathrm{LiAlH}_{4}(230 \mathrm{mg}, 0.65 \mathrm{mmol})$ in dry THF $(20 \mathrm{~mL})$ was refluxed for $3 \mathrm{~h}$ and then poured into a $5 \% \mathrm{HCl}$ solution $(100 \mathrm{~mL})$. The crude product was extracted with $\mathrm{CHCl}_{3}(3 \times 40 \mathrm{~mL})$, and then the organic layer was washed with $\mathrm{H}_{2} \mathrm{O}$, dried over $\mathrm{CaCl}_{2}$ and evaporated under reduced pressure. The product was purified by $\mathrm{Al}_{2} \mathrm{O}_{3}$ column chromatography using $\mathrm{CHCl}_{3}$ and a mixture of $\mathrm{CHCl}_{3}-\mathrm{EtOH}$ (100:1; $50: 1,25: 1,10: 1)$ as eluents to afford compound $5(187 \mathrm{mg}, 85 \%)$ or compound $6(174 \mathrm{mg}, 79 \%)$ as white powders.

3-Deoxy-3a-homo-3a-aza-lup-20(29)-en-28-methylenamine (5): $[\alpha]_{\mathrm{D}}{ }^{20}+96\left(\mathrm{c} 0.05, \mathrm{CHCl}_{3}\right)$, m.p. $246{ }^{\circ} \mathrm{C}$. ${ }^{1} \mathrm{H}-\mathrm{NMR}\left(\delta, \mathrm{ppm}, \mathrm{CDCl}_{3}, 125.5 \mathrm{MHz}\right): 4.68$ and $4.58(2 \mathrm{H}$, both $\mathrm{s}, J=2.0 \mathrm{~Hz}, \mathrm{H}-29), 3.80-3.78(1 \mathrm{H}, \mathrm{m}$, H3b), 3.35-3.29 (1H, m, H3a), 2.90-2.78 (2H, m, H-28), 2.40-1.65 (28H, m, CH, CH2), 1.65 (3H, s, H-30), 1.41, 1.17, 1.05, 0.99, 0.85 (15H, all s, 5CH3). ${ }^{13} \mathrm{C}-\mathrm{NMR}\left(\delta, \mathrm{ppm}, \mathrm{CDCl}_{3}, 500 \mathrm{MHz}\right): 151.0$ (C-20), 109.2 (C-29), 63.2 (C-3), 60.5, 54.4, 48.5, 47.8, 47.6, 47.4 (C-28), 43.0, 41.2, 40.9, 40.7, 37.7, 34.0, 29.7, 29.0, 27.9, 26.9, 25.8, 23.0, 22.9, 22.7, 22.0, 21.6, 21.3, 19.1, 16.6, 16.4, 14.5. Anal. Calcd for $\mathrm{C}_{30} \mathrm{H}_{52} \mathrm{~N}_{2}$ : C, 81.75; $\mathrm{H}, 11.89$; $\mathrm{N}, 6.36$. Found: $\mathrm{C}, 81.69 ; \mathrm{H}, 11.84 ; \mathrm{N}, 6.30$. MS (APCI): $\mathrm{m} / \mathrm{z}[\mathrm{M}+\mathrm{H}]^{+} 441.73$, calcd for $\mathrm{C}_{30} \mathrm{H}_{52} \mathrm{~N}_{2}: 440.75$.

3-Amino-3,4-seco-28-hydroxy-urs-12(13)-en (6): $[\alpha]_{\mathrm{D}}{ }^{20}+54$ (c 0.05, $\left.\mathrm{CHCl}_{3}\right)$, m.p. $195{ }^{\circ} \mathrm{C} .{ }^{1} \mathrm{H}-\mathrm{NMR}(\delta, \mathrm{ppm}$, $\left.\mathrm{CDCl}_{3}+\mathrm{C}_{5} \mathrm{D}_{5} \mathrm{~N}, 125.5 \mathrm{MHz}\right): 5.10(1 \mathrm{H}, \mathrm{s}, \mathrm{H}-12), 4.82$ and $4.78(2 \mathrm{H}$, both $\mathrm{d}, \mathrm{H}-23, J=2.8 \mathrm{~Hz}), 3.20$ and 3.40 (2H, both d, H-28), $3.10\left(2 \mathrm{H}, \mathrm{m}, \mathrm{CH}_{2} \mathrm{NH}_{2}\right), 2.15-1.00\left(25 \mathrm{H}, \mathrm{m}, \mathrm{CH}\right.$ and $\left.\mathrm{CH}_{2}\right), 1.65\left(3 \mathrm{H}, \mathrm{s}, \mathrm{CH}_{3}, \mathrm{H}-24\right)$, 1.22, 1.00, 0.92, 0.78, $0.66\left(15 \mathrm{H}\right.$, all s, $\left.5 \mathrm{CH}_{3}\right) .{ }^{13} \mathrm{C}-\mathrm{NMR}\left(\delta, \mathrm{ppm}, \mathrm{CDCl}_{3}+\mathrm{C}_{5} \mathrm{D}_{5} \mathrm{~N}, 500 \mathrm{MHz}\right): 148.7(\mathrm{C}-4)$, 139.2 (C-13), 123.3 (C-12), 115.4 (C-23), 69.9 (C-28), 51.8, 48.4, 43.9, 43.6, 41.8, 40.9, 40.6, 39.4, 38.7, 37.7, 35.8, 34.8, 32.9, 32.6, 32.5, 27.4, 27.1, 25.8, 25.2, 25.1, 24.6, 23.8, 23.0, 21.2, 18.1. Anal. Calcd for $\mathrm{C}_{30} \mathrm{H}_{51} \mathrm{NO}$ : C, 81.57; H, 11.64; N, 3.17. Found: C, 81.49; H, 11.70; N, 3.09. MS (APCI): $m / z[\mathrm{M}+\mathrm{H}]^{+} 442.73$, calcd for $\mathrm{C}_{30} \mathrm{H}_{51} \mathrm{NO}: 441.74$.

\subsection{Synthesis of Compounds 7-9}

To a solution of compound 1 (221 mg, $0.5 \mathrm{mmol}$ ) or compound 6 (220 mg, $0.5 \mathrm{mmol})$ in $\mathrm{CH}_{2} \mathrm{Cl}_{2}$ $(25 \mathrm{~mL})$ pyridinium chlorochromate (PCC) $(8.6 \mathrm{mg}, 1.2 \mathrm{mmol})$ was added and the mixture was stirred at room temperature until the starting material disappeared (monitored by TLC). After completion of the reaction, the mixture was passed through $\mathrm{Al}_{2} \mathrm{O}_{3}$, the organic phase was washed with $\mathrm{H}_{2} \mathrm{O}$ $(2 \times 30 \mathrm{~mL})$, dried over $\mathrm{CaCl}_{2}$ and evaporated under reduced pressure to yield crude aldehydes. Then, to a solution of betulonic aldehyde (110 $\mathrm{mg}, 0.25 \mathrm{mmol}$ ) [24] or freshly prepared above aldehydes in anhydrous $\mathrm{MeOH}(25 \mathrm{~mL})$, spermidine $(0.05 \mathrm{~mL}, 0.25 \mathrm{mmol}))$ was added and the reaction mixture was heated under reflux for $8 \mathrm{~h}$, then poured into $\mathrm{H}_{2} \mathrm{O}(50 \mathrm{~mL})$ and the precipitate was filtered off, washed with water, and dried in air. The products were chromatographed over $\mathrm{Al}_{2} \mathrm{O}_{3}$ using $\mathrm{CHCl}_{3}$ and a mixture of $\mathrm{CHCl}_{3}-\mathrm{EtOH}(100: 1 ; 50: 1)$ as eluents to afford compounds $7(100 \mathrm{mg}, 65 \%)$ as a yellow powder, $8(102 \mathrm{mg}, 72 \%)$ as a beige powder or $\mathbf{9}(109 \mathrm{mg}, 70 \%)$ as an orange powder.

3-Oxo-lup-20(29)-en-28-N-(4-aminobutyl)-N-propylamin-28-imine (7): $[\alpha]_{\mathrm{D}}{ }^{20}+3$ (c $\left.0.25, \mathrm{CHCl}_{3}\right)$, m.p. $201{ }^{\circ} \mathrm{C} .{ }^{1} \mathrm{H}-\mathrm{NMR}\left(\delta, \mathrm{ppm}, \mathrm{CDCl}_{3}, 125.5 \mathrm{MHz}\right): 7.82(1 \mathrm{H}, \mathrm{s}, \mathrm{CH}=\mathrm{N}), 4.62$ and $4.73(2 \mathrm{H}$, both $\mathrm{d}, J=2.0 \mathrm{~Hz}$, $\mathrm{H}-29), 3.50-2.68\left(8 \mathrm{H}, \mathrm{m}, 4 \mathrm{CH}_{2} \mathrm{~N}\right), 2.10-1.73\left(34 \mathrm{H}, \mathrm{m}, \mathrm{CH}, \mathrm{CH}_{2}\right), 1.72(3 \mathrm{H}, \mathrm{s}, \mathrm{H}-30), 1.09,1.08,1.01,0.98$, 
$0.89(15 \mathrm{H}$, all s, 5CH 3$) .{ }^{13} \mathrm{C}-\mathrm{NMR}\left(\delta, \mathrm{ppm}, \mathrm{CDCl}_{3}, 500 \mathrm{MHz}\right): 219.8$ (C-3), 170.9 (C-28), 150.0 (C-20), 110.1 (C-29), 57.3, 55.1, 49.8, 49.5, 49.3, 48.9, 48.0, 47.9, 47.4, 41.4, 41.2, 39.9, 39.6, 39.0, 37.7, 37.5, 34.3, 33.6, 32.2, 31.9, 30.8, 30.7, 29.0, 28.1, 27.5, 26.7, 25.5, 21.5, 21.0, 19.2, 16.6, 15.7, 14.9. Anal. Calcd for $\mathrm{C}_{37} \mathrm{H}_{63} \mathrm{~N}_{3} \mathrm{O}: \mathrm{C}, 78.53 ; \mathrm{H}, 11.22 ; \mathrm{N}, 7.43$. Found: $\mathrm{C}, 78.49 ; \mathrm{H}, 11.25 ; \mathrm{N}, 7.40$. MS (APCI): $m / z[\mathrm{M}+\mathrm{H}]^{+}$ 566.80, calcd for $\mathrm{C}_{37} \mathrm{H}_{63} \mathrm{~N}_{3} \mathrm{O}: 565.92$.

3-Deoxy-3a-homo-3a-aza-lup-20(29)-en-28-N-(4-aminobutyl)-N-propylamin-28-imine (8): $[\alpha]_{\mathrm{D}}{ }^{20}+85$ (c 0.1 , $\left.\mathrm{CHCl}_{3}\right)$, m.p. $185^{\circ} \mathrm{C} .{ }^{1} \mathrm{H}-\mathrm{NMR}\left(\delta, \mathrm{ppm}, \mathrm{CDCl}_{3}, 500 \mathrm{MHz}\right): 7.78(1 \mathrm{H}, \mathrm{s}, \mathrm{CH}=\mathrm{N}), 4.60$ and $4.72(2 \mathrm{H}$, both $\mathrm{d}, J=2.0 \mathrm{~Hz}, \mathrm{H}-29), 3.48-3.32(2 \mathrm{H}, \mathrm{m}, \mathrm{H} 3), 2.80-2.58\left(8 \mathrm{H}, \mathrm{m}, 4 \mathrm{CH}_{2} \mathrm{~N}\right), 2.10-1.42\left(35 \mathrm{H}, \mathrm{m}, \mathrm{CH}, \mathrm{CH}_{2}\right)$, $1.72(3 \mathrm{H}, \mathrm{s}, \mathrm{H}-30), 1.09,1.08,1.01,0.98,0.89\left(15 \mathrm{H}\right.$, all s, $\left.5 \mathrm{CH}_{3}\right) .{ }^{13} \mathrm{C}-\mathrm{NMR}\left(\delta, \mathrm{ppm}, \mathrm{CDCl}_{3}, 125.5 \mathrm{MHz}\right)$ : 169.1 (C-28), 150.2 (C-20), 109.8 (C-29), 62.3 (C-3), 58.0, 55.0, 52.2, 50.0, 48.7, 48.1, 47.8, 47.7, 42.9, 42.5, 41.4, 41.3, 39.2, 39.1, 37.4, 34.3, 34.0, 32.0, 31.5, 31.0, 30.1, 29.7, 29.4, 29.1, 28.0, 27.3, 26.9, 26.3, 23.2, 19.2, 16.8, 16.6, 14.3. Anal. Calcd for $\mathrm{C}_{37} \mathrm{H}_{66} \mathrm{~N}_{4}$ : C, 78.38; $\mathrm{H}, 11.73 ; \mathrm{N}, 9.88$. Found: $\mathrm{C}, 78.32 ; \mathrm{H}, 11.70 ; \mathrm{N}, 9.85$. MS (APCI): $m / z[\mathrm{M}+\mathrm{H}]^{+}$567.93, calcd for $\mathrm{C}_{37} \mathrm{H}_{66} \mathrm{~N}_{4}: 566.95$.

3-Amino-3,4-seco-urs-12(13)-en-28-N-(3-aminopropyl)-N-(butane-1,4-diamine)-N-propylamin-28-imine (9): $[\alpha]_{\mathrm{D}}{ }^{20}+91\left(\mathrm{c} 0.1, \mathrm{CHCl}_{3}\right)$, m.p. $145^{\circ} \mathrm{C} .{ }^{1} \mathrm{H}-\mathrm{NMR}\left(\delta, \mathrm{ppm}, \mathrm{CDCl}_{3}, 125.5 \mathrm{MHz}\right): 7.31(1 \mathrm{H}, \mathrm{s}, \mathrm{CH}=\mathrm{N}$, $\mathrm{H}-28), 5.10(1 \mathrm{H}, \mathrm{s}, \mathrm{H}-12), 4.79$ and $4.59(2 \mathrm{H}$, both $\mathrm{d}, \mathrm{H}-23, J=2.8 \mathrm{~Hz}), 3.68-2.58\left(8 \mathrm{H}, \mathrm{m}, 4 \mathrm{CH}_{2} \mathrm{~N}\right)$, 2.00-1.63 (36H, m, CH and $\left.\mathrm{CH}_{2}\right), 1.62\left(3 \mathrm{H}, \mathrm{s}, \mathrm{CH}_{3}, \mathrm{H}-24\right), 1.18,0.99,0.90,0.74,0.65\left(15 \mathrm{H}\right.$, all s, $\left.5 \mathrm{CH}_{3}\right)$. ${ }^{13} \mathrm{C}-\mathrm{NMR}\left(8, \mathrm{ppm}, \mathrm{CDCl}_{3}, 500 \mathrm{MHz}\right): 173.6$ (C-28), 147.9 (C-4), 139.5 (C-13), 125.2 (C-12), 113.2 (C-23), 54.2, 52.2, 50.4, 42.6, 41.6, 41.4, 40.6, 39.7, 39.1, 38.3, 37.7, 36.5, 35.3, 33.9, 32.3, 31.8, 31.6, 30.6, 29.7, 29.3, 28.0, 26.0, 25.6, 24.4, 23.6, 23.3, 23.0, 21.9, 21.3, 20.7, 20.1, 19.9. Anal. Calcd for $\mathrm{C}_{37} \mathrm{H}_{66} \mathrm{~N}_{4}$ : Found: $\mathrm{C}$, 78.38; H, 11.73; N, 9.88. Found: C, 78.29; H, 11.84; N, 9.79. MS (APCI): $m / z[\mathrm{M}+\mathrm{H}]^{+} 567.94$, calcd for $\mathrm{C}_{37} \mathrm{H}_{66} \mathrm{~N}_{4}: 566.95$.

\subsection{Synthesis of 3-oxo-urs-12(13)-en-28-N-(2-((2-aminoethyl)amino)ethyl)-2-ethylamide (10)}

A solution of ursonic acid [22] $(225 \mathrm{mg}, 0.5 \mathrm{mmol})$ in dry $\mathrm{CH}_{2} \mathrm{Cl}_{2}(20 \mathrm{~mL})$ and $(\mathrm{COCl})_{2}(1.5 \mathrm{mmol}$, $0.13 \mathrm{~mL}$ ) was stirred at room temperature for $2 \mathrm{~h}$ and then was concentrated to dryness under reduced pressure. A resulting ursonic acid chloride $(235 \mathrm{mg}, 0.5 \mathrm{mmol})$ was dissolved in dry $\mathrm{CH}_{2} \mathrm{Cl}_{2}(30 \mathrm{~mL})$ and treated with diethylenetriamine $(0.05 \mathrm{~mL}, 0.5 \mathrm{mmol})$ and $\mathrm{Et}_{3} \mathrm{~N}(0.07 \mathrm{~mL}, 0.5 \mathrm{mmol})$. It was then stirred at room temperature for $3 \mathrm{~h}$, washed with $5 \% \mathrm{HCl}$ solution $(2 \times 50 \mathrm{~mL})$ and $\mathrm{H}_{2} \mathrm{O}(50 \mathrm{~mL})$, dried over $\mathrm{CaCl}_{2}$, and the solvent was removed under reduced pressure. The product was chromatographed over a column of $\mathrm{Al}_{2} \mathrm{O}_{3}$ using $\mathrm{CHCl}_{3}$ and a mixture of $\mathrm{CHCl}_{3}$-EtOH $(100: 1 ; 70: 1,40: 1)$ as eluents to afford compound $10(229 \mathrm{mg}, 85 \%)$ as a yellow powder. $[\alpha]_{\mathrm{D}}{ }^{20}+35\left(\mathrm{c} 0.1, \mathrm{CHCl}_{3}\right)$, m.p. $178^{\circ} \mathrm{C}$. ${ }^{1} \mathrm{H}-\mathrm{NMR}\left(\delta, \mathrm{ppm}, \mathrm{CDCl}_{3}, 125.5 \mathrm{MHz}\right): 6.61(1 \mathrm{H}, \mathrm{s}, \mathrm{CONH}), 5.30(1 \mathrm{H}, \mathrm{s}, \mathrm{H}-12), 4.50-4.25(3 \mathrm{H}, \mathrm{m}, \mathrm{NH}$, $\left.\mathrm{NH}_{2}\right), 3.70-2.70\left(8 \mathrm{H}, \mathrm{m}, 4 \mathrm{CH}_{2}\right), 2.55-1.36\left(23 \mathrm{H}, \mathrm{m}, \mathrm{CH}\right.$ and $\left.\mathrm{CH}_{2}\right), 1.35,1.19,1.10,0.99,0.89,0.75$, $0.65\left(21 \mathrm{H}\right.$, all s, $\left.7 \mathrm{CH}_{3}\right) .{ }^{13} \mathrm{C}-\mathrm{NMR}\left(8, \mathrm{ppm}, \mathrm{CDCl}_{3}, 500 \mathrm{MHz}\right): 217.6(\mathrm{C}-3), 178.9(\mathrm{C}-28), 139.4(\mathrm{C}-13)$, 126.8 (C-12), 58.1, 55.2, 54.9, 53.4, 52.5, 48.3, 47.4, 46.7, 42.2, 39.7, 39.5, 38.9, 37.3, 36.6, 34.1, 32.6, 30.9, 28.1, 27.8, 26.6, 24.8, 24.6, 23.5, 23.3, 21.2, 19.6, 19.1, 18.8, 18.4, 17.2. Anal. Calcd for $\mathrm{C}_{34} \mathrm{H}_{57} \mathrm{~N}_{3} \mathrm{O}_{2}$ : C, 75.65; H, 10.64; N, 7.78. Found: C, 75.59; H, 10.58; N, 7.70. MS (APCI): $m / z[\mathrm{M}+\mathrm{H}]^{+} 540.82$, calcd for $\mathrm{C}_{34} \mathrm{H}_{57} \mathrm{~N}_{3} \mathrm{O}_{2}: 539.84$.

\section{Biology Methods}

\section{Determination of Minimal Inhibitory Concentrations}

The antimicrobial activity of the compounds 1, 2, 5, and 7-11 was studied by determination of minimal inhibitory concentrations (MICs) according to the NCCLS guidelines M7-A2 using the microbroth dilution methods. All of the strains were issued from the Institute Pasteur collection (Paris, France). The bacteria strains were grown on trypticase soy agar (Becton Dickinson) at $37^{\circ} \mathrm{C}$ for $24 \mathrm{~h}$ (E. coli ATCC25299, S. aureus DSM789, P. aeruginosa (PA01)) in MHII broth for P. aeruginosa, 
E. coli and S. aureus. Inocula were prepared in MHII by adjusting the turbidity at $623 \mathrm{~nm}$ to obtain $10^{6} \mathrm{CFU} / \mathrm{mL}$.

Antimicrobial activities of the compounds were determined by using a broth microdilution method performed in sterile 96-well microplates. All compounds were solubilized in methanol at a concentration of $5 \mathrm{mg} / \mathrm{mL}$ and were transferred to each microplate well (in all cases concentrations of the desired molecules in methanol did not exceed $2 \%$ of the total proportion). In order to obtain a two-fold serial dilution, $100 \mu \mathrm{L}$ of broth and $100 \mu \mathrm{L}$ of inocula containing $5 \times 10^{5}-10^{6} \mathrm{CFU}$ of each bacteria were added to each well. Several wells were reserved for positive controls, inoculum viability, and solvent effect. After $24 \mathrm{~h}$ incubation, growth was assayed by absorbance measurement at $623 \mathrm{~nm}$ with an IEMS Labsystem automatic plate reader. MIC was defined for each agent from triplicate observations as the lowest concentration of compound allowing no visible growth.

\section{Conclusions}

Finally, a series of triterpenoid C-28 polyamine conjugates or A-azepanes was synthesized and evaluated for their antimicrobial activity. Among them, oleanonic acid amide with diethylentriamine appears to be an interesting antimicrobial candidate against both Gram-positive and Gram-negative bacteria. Current studies are underway to evaluate the potentiality of such derivatives in vivo, by determining the cytotoxicity of these compounds, establishing the mechanism of action of this new class of antimicrobial agents and designing more active derivatives by varying the nature of the polyamine chain involved.

Supplementary Materials: The following are available online, Figures S1-S18: ${ }^{1} \mathrm{H}$ and ${ }^{13} \mathrm{C}$ spectra for compounds 1, 2, 5-11, Scheme S1: Full synthetic route from betulin to compounds 1, 2 and 8 and from betulonic aldehyde to compounds 3, 5 and 7, Scheme S2: Full synthetic route from ursonic and oleanonic acids to compounds 4, 6 and 9-11.

Author Contributions: O.B.K. brought the idea, managed the research, conducted some synthetic experiments and prepared the manuscript; S.N. conducted some biological experiments, E.F.K. managed the research and prepared the manuscript; G.V.G. and T.V.L. conducted some synthetic experiments; A.V.P. made structure elucidation and prepared the manuscript; J.M.B. brought the idea, conducted biological experiments and prepared the manuscript.

Funding: The synthesis of compounds 1-3, $\mathbf{5}$ and $\mathbf{8}$ was supported by the Russian Foundation for Basic Research (project no. 18-33-00364 mol_a to Tatyana V. Lopatina).

Acknowledgments: This work was supported by the Ministry of Education of the Russian Federation, State task projects no. AAAA-A17-117011910023-2 and AAAA-A19-119020890014-7. The study of antimicrobial activity was supported by Aix-Marseille Université.

Conflicts of Interest: The authors declare no conflict of interest.

\section{References}

1. Salvador, J.A.R.; Leal, A.S.; Valdeira, A.S.; Gonçalves, B.M.F.; Alho, D.P.S.; Figueiredo, S.A.C.; Silvestre, S.M.; Mendes, V.I.S. Oleanane-, ursane-, and quinone methide friedelane-type triterpenoid derivatives: Recent advances in cancer treatment. Eur. J. Med. Chem. 2017, 142, 95-130. [CrossRef] [PubMed]

2. Sousa, J.L.C.; Freire, C.S.R.; Silvestre, A.J.D.; Silva, A.M.S. Recent developments in the functionalization of betulinic acid and its natural analogues: A route to new bioactive compounds. Molecules 2019, 24, 355. [CrossRef] [PubMed]

3. Kvasnica, M.; Urban, M.; Dickinson, N.J.; Sarek, J. Pentacyclic triterpenoids with nitrogen- and sulfur-containing heterocycles: Synthesis and medicinal significance. Nat. Prod. Rep. 2015, 32, 1303-1330. [CrossRef] [PubMed]

4. Smirnova, I.E.; Kazakova, O.B. Structure - Anti-influenza Type a Activity Relationship among a Series of Nitrogen Lupane Triterpenoids. Nat. Prod. Commun. 2018, 13, 1267-1270. [CrossRef]

5. Bildziukevich, U.; Rarova, L.; Janovska, L.; Saman, D.; Wimmer, Z. Enhancing effect of cystamine in its amides with betulinic acid as antimicrobial and antitumor agent in vitro. Steroids 2019, 148, 91-98. [CrossRef] [PubMed] 
6. Khusnutdinova, E.F.; Apryshko, G.N.; Petrova, A.V.; Kukovinets, O.S.; Kazakova, O.B. The synthesis and selective cytotoxicity of new Mannich bases derivatives of 19- and 28-alkynyltriterpenoids. Russ. J. Bioorg. Chem. 2018, 1, 123-127. [CrossRef]

7. Bildziukevich, U.; Kaletova, E.; Saman, D.; Sievanen, E.; Kolehmainen, E.T.; Slouf, M.; Wimmer, Z. Spectral and microscopic study of self-assambly of novel cationic spermine amides of betulinic acid. Steroids 2017, 117, 90-96. [CrossRef]

8. Kahnt, M.; Hoenke, S.; Fischer, L.; Al-Harrasi, A.; Csuk, R. Synthesis and cytotoxicity evaluation of DOTA-conjugates of ursolic acid. Molecules 2019, 24, 2254. [CrossRef]

9. Foster, T.J. The Staphylococcus aureus "superbug". J. Clin. Investig. 2004, 114, 1693-1696. [CrossRef]

10. Boman, H.G. Antibacterial peptides: Key components needed in immunity. Cell 1991, 65, 205-207. [CrossRef]

11. Zasloff, M. Antibacterial molecules from frogs, sharks and man. In Phylogenetic Perspective in Immunity: The Insect-Host Defense; Hoffmann, J., Natori, S., Janeway, C., Eds.; RG Landes Biomedical Publisher: Austin, TX, USA, 1994; pp. 31-41.

12. Cho, J.; Kim, Y. Sharks: A potential source of antiangiogenic factors and tumor treatments. Mar. Biotechnol. 2002, 4, 521-525. [CrossRef] [PubMed]

13. Moore, K.S.; Wehrli, S.; Roder, H.; Rogers, M.; Forrest, J.N., Jr.; McCrimmon, D.; Zasloff, M. Squalamine: An aminosterol antibiotic from the shark. Proc. Natl. Acad. Sci. USA 1993, 90, 1354-1358. [CrossRef] [PubMed]

14. Brunel, J.M.; Letourneux, Y. Recent advances in the synthesis of spermine and spermidine analogs of the shark aminosterol squalamine. Eur. J. Org. Chem. 2003, 3897-3907. [CrossRef]

15. Alhanout, K.; Rolain, J.M.; Brunel, J.M. Squalamine as an example of a new potent antimicrobial agent class: A critical review. Curr. Med. Chem. 2010, 17, 3909-3917. [CrossRef] [PubMed]

16. Kazakova, O.B.; Giniyatullina, G.V.; Medvedeva, N.I.; Tolstikov, G.A. Synthesis of a triterpene-spermidine conjugate. Russ. J. Bioorg. Chem. 2012, 45, 1366-1369. [CrossRef]

17. Djouhri-Bouktab, L.; Vidal, N.; Rolain, J.M.; Brunel, J.M. Synthesis of new 3,20-bispolyaminosteroid squalamine analogues and evaluation of their antimicrobial activities. J. Med. Chem. 2011, 54, 7417-7421. [CrossRef]

18. Blanchet, M.; Borselli, D.; Rodallec, A.; Peiretti, F.; Vidal, N.; Bolla, J.M.; Digiorgio, C.; Morrison, K.R.; Wuest, W.M.; Brunel, J.M. Claramines: A new class of broad-spectrum antimicrobial agents with bimodal activity. Chem. Med. Chem. 2018, 13, 1018-1027. [CrossRef]

19. Bildziukevich, U.; Vida, N.; Rarova, L.; Kolar, M.; Saman, D.; Havlicek, L.; Drasar, P.; Wimmer, Z. Polyamine derivatives of betulinic acid and $\beta$-sitosterol: A comparative investigation. Steroids 2015, 100, 27-35. [CrossRef]

20. Medvedeva, N.I.; Kazakova, O.B.; Lopatina, T.V.; Smirnova, I.E.; Giniyatullina, G.V.; Baikova, I.P.; Kataev, V.E. Synthesis and antimycobacterial activity of triterpenic A-ring azepanes. Eur. J. Med. Chem. 2018, 143, 464-472. [CrossRef]

21. Khusnutdinova, E.F.; Petrova, A.V.; Thu, H.N.; Tu, A.L.; Thanh, T.N.; Thi, C.B.; Babkov, D.A.; Kazakova, O.B. Structural modifications of 2,3-indolobetulinic acid: Design and synthesis of highly potent $\alpha$-glucosidase inhibitors. Bioorg. Chem. 2019, 88, 102957. [CrossRef]

22. Dalla-Vechia, L.; Dassonville-Klimpt, A.; Grellier, P.; Sonnet, P.; Gosmann, G.; Gnoatto, S.C.B. The Beckmann rearrangement applied to ursolic acid with antimalarial activity in medicinal chemistry studies. Lett. Org. Chem. 2012, 9, 92-95. [CrossRef]

23. Giniyatullina, G.V.; Kazakova, O.B.; Salimova, E.V.; Tolstikov, G.A. Synthesis of new betulonic and oleanolic acid amides. Chem. Nat. Compd. 2011, 47, 68-72. [CrossRef]

24. Flekhter, O.B.; Ashavina, O.Y.; Boreko, E.I.; Karachurina, L.T.; Pavlova, N.I.; Kabal'nova, N.N.; Savinova, O.V.; Galin, F.Z.; Nikolaeva, S.N.; Zarudii, F.S.; et al. Synthesis of 3-acetylbetulinic acid and betulonic aldehydes according to Svern and the pharmacological activity of related oximes. Pharm. Chem. J. 2002, 36, 303-306. [CrossRef]

(C) 2019 by the authors. Licensee MDPI, Basel, Switzerland. This article is an open access article distributed under the terms and conditions of the Creative Commons Attribution (CC BY) license (http://creativecommons.org/licenses/by/4.0/). 